\title{
Beyond the Writing Aspect of Argument-Driven Inquiry: Investigating Students' Cognitive and Affective Expectations
}

\author{
Pınar Seda ÇETİN*a, Gülüzar EYMUR ${ }^{\mathrm{b}}$
}

\begin{tabular}{l} 
Article Info \\
\hline DOI: $10.14686 /$ buefad.376998 \\
\hline Article History: \\
Received $\quad 10.01 .2018$ \\
Revised $\quad 01.02 .2018$ \\
Accepted $\quad 02.02 .2018$ \\
\hline Keywords: \\
Argument-Driven Inquiry \\
Laboratory Instruction, \\
Meaningful Learning. \\
\hline Article Type: \\
Research Article \\
\hline
\end{tabular}

\begin{abstract}
The purpose of the present study was to investigate whether pre-service teachers' cognitive and affective expectations were met after participation of lab investigations that were designed based on the ADI instructional model. Based on Novak' theory of learning, when the students get responsibilities to connect new knowledge with existing one, students stand active role in generating knowledge through experiences. In order to determine whether the cognitive and affective expectations of pre-service teachers are fulfilled by their experiences in a science laboratory course, weak experimental design was utilized in this study. Participants' experiences and expectations were measured with Meaningful Learning in the Laboratory Instrument developed by Galloway and Bretz (2015). Third grade pre-service science teachers attended ADI activities as a part of their regular course through 11 weeks. Through ADI activities pre- service teachers had a chance to engage variety of scientific activities such as designing investigations, arguing from evidence, writing scientific reports, and critically evaluating peers' reports.
\end{abstract}

\section{Argümantasyon Tabanlı Sorgulayıcı Araştırma Yönteminin Yazmaya Etkisinin Ötesinde: Öğrencilerin Bilişsel ve Duyuşsal Beklentilerinin İncelenmesi}

\begin{tabular}{|c|c|}
\hline \multicolumn{2}{|c|}{ Makale Bilgisi } \\
\hline \multicolumn{2}{|c|}{ DOI: $10.14686 /$ buefad.376998 } \\
\hline \multicolumn{2}{|c|}{ Makale Geçmişi: } \\
\hline Geliş & 10.01 .2018 \\
\hline Düzeltme & 01.02 .2018 \\
\hline Kabul & 02.02 .2018 \\
\hline \multicolumn{2}{|c|}{$\begin{array}{l}\text { Anahtar Kelimeler: } \\
\text { Argümantasyon Tabanlı } \\
\text { Sorgulayıcı Araştırma, } \\
\text { Laboratuvar Ögretimi, } \\
\text { Anlamlı Öğrenme. }\end{array}$} \\
\hline $\begin{array}{l}\text { Makale Ti } \\
\text { Araştırma }\end{array}$ & akalesi \\
\hline
\end{tabular}

\begin{abstract}
Öz
$\mathrm{Bu}$ çalışmanın amacı, Argümantasyon Tabanlı Sorgulayıcı Araştırma (ATSA) yöntemine göre tasarlanmış laboratuvar uygulamalarına katılan öğretmen adaylarının bilişsel ve duyuşsal beklentilerinin karşılanıp karşılanmadığını incelemektir. Novak, insanların bu deneyimlerini bilişsel (düşünme), duyuşsal (hissetme) ve psikomotor (yapma) olmak üzere üçe ayırmıştır. Bu çalışmada, öğretmen adaylarının fen laboratuvarındaki bilişsel ve duyuşsal beklentilerinin, deneyimleri tarafindan karşılanıp karşılanmadığını Galloway ve Bretz (2015) tarafından geliştirilen Laboratuvarda Anlamlı Öğrenme Ölçeği ile belirlemek amacıyla zayıf deneysel desen kullanılmıştır. Üçüncü sınıf fen bilgisi öğretmen adayları 11 hafta boyunca düzenli derslerinin bir parçası olarak ATSA etkinliklerine katılmıştır.
\end{abstract}

\footnotetext{
*Corresponding Author: pnrsarier@gmail.com

a Assoc. Prof. Dr., Abant İzzet Baysal University, Bolu /Turkey, https://orcid.org/0000-0003-4299-0893

bAsst. Prof. Dr., Giresun University, Giresun, Turkey, https://orcid.org/0000-0002-3316-5464
} 


\section{Introduction}

The important and critical role of laboratory activities in developing scientifically literate students has been addressed in many education researches (Cetin \& Eymur, 2017; Cheung, 2011; Figueiredo, Esteves, Neves, \& Vicente, 2016; Obenland, Kincaid, \& Hutchinson, 2014; Walker, Sampson, Southerland, \& Enderle, 2016). Moreover, it is also a common conclusion of these researches that traditionally designed science laboratories have used to present concepts related science courses and unfortunately give little opportunity to students to practice in science (Cooper \& Kerns, 2006). Many laboratories are thus designed to provide students observe the findings and get conclusions from these findings. Although these "cookbook" style laboratories may give a lot of knowledge related in many topics, indeed there is no meaningful learning for students (Domin, 1999; Hofstein \& Lunetta, 2004). Regard to this finding, many science education researchers have started to design novel laboratory instructional models such as Science Writing Heuristic (Wallace, Hand, \& Yang, 2005) and Modeling Instruction (Hestenes, 1992; Wells, Hestenes, \& Swackhamer, 1995) that mainly focus on knowledge construction and inquiry. The Argument-Driven Inquiry (ADI) is a similar laboratory instructional model emphasizes on not only the empirical aspects of laboratories (such a asking questions, designing methods) but also gives great importance to representation of knowledge claims (such as argumentation, writing) in the development of students' science proficiency. This model gives students a chance to engage in meaningful learning by getting active role in scientific practices such as designing investigations and criticizing results.

According to Novak's theory of meaningful learning, the student should have related background knowledge, the new knowledge should be given in a meaningful way to the student and the student should want actively engage in the learning process (Bretz, 2001; Novak, 1993, 2010). When the students get responsibilities to connect new knowledge with present knowledge, the students stand active role in generating knowledge through experiences (Bretz, 2001; Novak, 1993, 2010). Novak categorized these human experiences as cognitive (thinking), affective (feeling), and psychomotor (doing). The successful consolidation of the cognitive, affective and psychomotor experiences then result in meaningful learning (Novak, 2010). As ADI model support students to engage in meaningful learning, it deserves to investigate whether students' cognitive and affective expectations about ADI instructional model can be met or not.

The ADI have eight interrelated steps that presented by Sampson and Walker to support students to get meaningful learning in Table 1 (Çetin, Metin, \& Kaya, 2016).

Table 1. The steps of ADI instructional model and purposes

\begin{tabular}{ll}
\hline \multicolumn{1}{c}{ Step } & \multicolumn{1}{c}{ Purpose } \\
\hline $\begin{array}{l}\text { Identification of Task and the } \\
\text { Research Question }\end{array}$ & $\begin{array}{l}\text { Attract students' attention } \\
\text { Activate students' previous knowledge }\end{array}$ \\
\hline $\begin{array}{l}\text { Develop a Method; Collect and } \\
\text { Analyze Data }\end{array}$ & $\begin{array}{l}\text { Give a chance to students to design and practice an investigation. } \\
\text { Provide an opportunity to students to decide what type of data they } \\
\text { need and how they collect }\end{array}$ \\
\hline $\begin{array}{l}\text { Generation of a Tentative } \\
\text { Argument }\end{array}$ & $\begin{array}{l}\text { Give an opportunity to students to develop tentative argument that } \\
\text { include claim, evidence and justification of evidence }\end{array}$ \\
\hline Argumentation session & $\begin{array}{l}\text { Make students discuss and share their ideas } \\
\text { Give a chance to students to get feedback about their argument }\end{array}$ \\
\hline Open and Reflective Discussion & $\begin{array}{l}\text { Make students share the knowledge and experiences that have gained } \\
\text { from sharing with their friends in other groups }\end{array}$ \\
\hline Write an Investigation Report & Make students learn how to craft written argument \\
\hline
\end{tabular}




\begin{tabular}{ll}
\hline $\begin{array}{l}\text { Double-Blind Group Peer } \\
\text { Review }\end{array}$ & $\begin{array}{l}\text { Give a chance to students to understand good quality investigation } \\
\text { report } \\
\text { Provide an opportunity to students to get feedback from their peers. }\end{array}$ \\
\hline Revise Investigation Reports & Make students revise and improve their writing \\
\hline
\end{tabular}

In literature, there have been some researches that investigate the effectiveness of ADI to develop high school students' biology and college students' chemistry proficiency in the US (Strimaitis, Southerland, Enderle, Grooms, \& Sampson, 2017). Generally, most of the researches about ADI are related to effectiveness of ADI on writing skills (Sampson \& Walker, 2012; Walker, Sampson, Grooms, Anderson, \& Zimmerman, 2012). Based on literature, there is no doubt that ADI instructional model help students' better writing in science. However, there is no study about the effect of the ADI practices on students' cognitive and affective expectations. The purpose of present study was to investigate whether pre-service teachers' cognitive and affective expectations were met after participation of six lab investigations that were designed based on the ADI instructional model.

\section{Theoretical Framework of the ADI}

The ADI laboratory instructional model stands up to social constructivist theories of learning (Driver, Asoko, Leach, Mortimer, \& Scott, 1994; Anderson, 2007; Scott, Asoko, \& Leach, 2007). This approach of learning is grounded a fundamental assumption that the knowledge cannot be transferred from one individual to another, but is actively established by the learner (Driver, Asoko, Leach, Mortimer, \& Scott, 1994). This establishment takes place by individually and social processes. The social process of learning relies on supportive and educative interactions with people while the personal process involve individual construction of knowledge and understanding. There are two significant results of this theoretical framework for instructional design. One of them is that students need authentic scientific practices in order to learn from their experiences. Another is that the scientific practices should also be educative for students to learn scientific knowledge and norms.

Duschl, Schweingruber and Shouse define argumentation as "logical discourse whose goal is to tease out the relationship between ideas and evidence" (Duschl, Schweingruber \& Shouse, 2007, p.33).Scientific argumentation should be included claim, evidence and justification of evidence. The evidence means the data that are collected and then used to support to claim by proofing and clarifying. There are two conditions for this data to be considered evidence. It should explain (1) tendency over time, (2) a difference between groups or (3) a relationship. The justification of evidence of a scientific argumentation refers to explanation of the validity and the relevance of the evidence. Based on theoretical background, the ADI instructional model is founded on the hypothesis that gives students an opportunity in actively engaging more authentic and educative laboratory activities. We think that ADI can meet students' positive cognitive and affective expectations about laboratory by giving students active role in constructing knowledge through experiences.

\section{Research Question}

Based on the purpose of study, the research question that runs this study is as follow:

Do the scientific practices of pre-service science teachers in the science laboratory course designed according to ADI instructional model facilitate to meet cognitive and affective expectations of them?

\section{Method}

In order to determine whether the cognitive and affective expectations of pre-service teachers are fulfilled by their experiences in a science laboratory course, one group pre- test post-test design was utilized in this study. 


\section{Subject of the study}

32 (28 female, 4 male) third grade pre-service science teachers from a public university participated in the study. The students' ages ranged from 21 to 23 years. The students were attending Science Laboratory course that was taught by an instructor experienced in ADI model in the first semester of the 2014/ 2015 academic year. Before the study participants completed General Chemistry I-II, General Biology I-II, and General Physics I-II laboratories. These pre-service teachers were selected due to their convenient accessibility and proximity to the researcher.

\section{Instrument}

In this study Meaningful Learning in the Laboratory Instrument (MLLI) developed by Galloway and Bretz (2015) was used. The aim of the instrument is to measure students' expectations and experiences related to the cognitive and affective dimensions of their learning in a laboratory course. The original version of the instruments was developed for the use in chemistry laboratory. Researchers adopted the items for science in general in order to understand students' experiences/expectation in science laboratories. The instrument includes 31 items (16 cognitive, 8 affective, 6 cognitive/affective) with five point likert type from Strongly Disagree (1) to Strongly Agree (5). Participants were asked to indicate their degree of agreement with each statement. There are 14 negatively worded items and they were reverse coded in order that higher score represents higher contribution to meaningful learning. The researchers translated the items into Turkish independently, and then they came together to negotiate and solve the conflicts. The final version of the test was checked by an expert in Turkish and science education in order to ensure the appropriateness of items.

\section{Procedure}

Third grade pre-service science teachers attended the ADI activities as a part of their regular course through 11 weeks. The teacher made students as a group of three or four randomly. Ten groups attended 4-hour lab session each week and they engaged six ADI activities. The ADI activities are related to chemistry, biology and physics. These activities are designed to explore the concept of density, gases, germination, power of lamp, enzymes and simple pendulum (Table 2). These activities were previously piloted by the researchers and tested whether they works as intented in science laboratories (Cetin \& Eymur, 2017; Eymur \& Cetin, 2017; Erenler, 2017).

Table 2. Description of activities

\begin{tabular}{ll}
\hline Name of the activity & Guiding question \\
\hline Density & What are the identities of unknown matters? \\
Gases & What is the relationship between volume and temperature of gases? \\
Germination & What are the factors affecting germination? \\
Power of lamp & What are the factors affecting power of lamp? \\
Enzymes & What are the factors affecting working of enzymes? \\
Simple Pendulum & What are the factors affecting oscillation rate of pendulum? \\
\hline
\end{tabular}

Each ADI investigation started with teacher's distribution of a handout containing guiding research question of the week, relevant background information and a list of available materials that pre-service teachers could use to design their investigation. The guiding questions for each activity are given in Table 2. Pre-service teachers worked in groups to design and conduct an investigation to answer the research question. For example for the density activity they tried to find ways to measure the mass and volume of powdered matter. Each group had different design to measure the volume (e.g. pouring to graduated cyclinder, dissolving in water, compressed it to reduce empty space etc) After data collection, they produced a tentative scientific argument by analyzing and interpreting their data. "The unknown matter is salt. Since I found its density as 2,1 and from the given density list it is near the salts' density" is an example of their argument. They used a large whiteboard to show their arguments to other groups for argumentation session. During the argumentation session, students presented their scientific arguments to other groups and critiqued the scientific arguments presented by their colleagues. During this session they generally criticized other groups ways of collecting and interpreting data After argumentation session, each group made reflective discussion to share experiences and thoughts. After this opportunity, each student individually wrote an investigation report to answer the guiding research question and submitted it to the classroom 
teacher. The individually written reports which are blinded were peer reviewed to provide opportunity to refine written scientific arguments. In the final step of the ADI instructional model, each pre-service teacher revised his or her individual investigation report based on the peer feedback.

\section{Findings and Discussion}

This part presented descriptive analysis and their outcomes for the research question. Also, the brief discussion was given based on the research question and outcomes of analyses. Table 3 shows the descriptive statistics for the cognitive, affective and cognitive/affective dimensions of MLLI for expectations (pre-test) and experiences (post-test).

Table 3. Descriptive Statistics for MLLI pre- and post-test

\begin{tabular}{llllll}
\hline Dimensions of MLLI & $\begin{array}{l}\text { Number of } \\
\text { students }\end{array}$ & Minimum & Maximum & Mean & $\begin{array}{l}\text { Standart } \\
\text { Deviation }\end{array}$ \\
\hline Pre-cognitive & 32 & 43 & 61 & 52,0 & 6,2 \\
Post-cognitive & 32 & 42 & 65 & 53,0 & 5,1 \\
Pre- affective & 32 & 14 & 67 & 24,8 & 7,9 \\
Post-affective & 32 & 17 & 71 & 29,0 & 8,7 \\
Pre & 32 & 10 & 22 & 21,1 & 3,0 \\
cognitive/affective & & & & & 2,8 \\
\hline Post & 32 & 12 & 26 & & \\
cognitive/affective & & & & & \\
\hline
\end{tabular}

As it is seen in Table 3 pre-service science teachers' pre and post-test scores in cognitive dimension are very similar $(\bar{X}=52$ for pretest and $\bar{X}=53$ for posttest). Similarly their scores in cognitive/affective dimension from pre- to post- test changed very slightly ( $\bar{X}=21.1$ for pretest and $\bar{X}=20.5$ for posttest.). The unchanged scores of students can be interpreted as their expectation was fulfilled by their experiences. When we examine affective dimension, it can be seen that their scores increased from pre- to post-test which means students experiences are much better than their expectations $(\bar{X}=24.8$ for pretest and $\bar{X}=29$ for posttest). Finally, since there is no significant decrease in any scores taken from three dimensions from pre- to post- test we can conclude that preservice teachers' experiences did not surpass their expectation.

Given the overall fulfilled expectation, a finer grain analysis of items was conducted. In table 4, the mean preand post-test scores of all items are presented. We showed the items that the participant got higher scores from the post-test (their experiences are better than their expectation) in bold.

$\underline{\text { Table 4. Pre and post- test mean scores of Items (Items were taken from pre-test version) }}$

\begin{tabular}{|c|c|c|c|}
\hline Items & Dimension & $\begin{array}{l}\text { Pre-test } \\
\text { mean score }\end{array}$ & $\begin{array}{l}\text { Post-test } \\
\text { mean score }\end{array}$ \\
\hline \multicolumn{4}{|l|}{$\begin{array}{l}\text { When performing experiments in my } \\
\text { science laboratory course this semester, I } \\
\text { expect............(pre-test) }\end{array}$} \\
\hline \multicolumn{4}{|l|}{$\begin{array}{l}\text { When performing experiments in my } \\
\text { science laboratory course this semester, } \\
\text { I...........(past simple form of verbs of the } \\
\text { following phrases were used in items) (post- } \\
\text { test) }\end{array}$} \\
\hline to learn science that will be useful in my life. & Cognitive/Affective & 3,9 & 3,7 \\
\hline to worry about finishing on time. & Affective & 2,5 & 3,3 \\
\hline
\end{tabular}




\section{to make decisions about what data to collect.}

to feel unsure about the purpose of the procedures.

to experience moments of insight.

to be confused about how the instruments

work.

to learn critical thinking skills.

to be excited to do science.

to be nervous about making mistakes. to consider if my data makes sense.

to think about what the molecules are doing.

to feel disorganized.

to develop confidence in the laboratory.

to worry about getting good data.

the procedures to be simple to do.

to be confused about the underlying concepts.

to "get stuck" but keep trying.

to be nervous when handling chemicals.

to think about science I already know.

to worry about the quality of my data.

to be frustrated.

to interpret my data beyond only doing calculations.

to focus on procedures, not concepts.

to use my observations to understand the

behavior of atoms and molecules

to make mistakes and try again.

to be intrigued by the instruments.

to feel intimidated.

to be confused about what my data mean.

to be confident when using equipment.

to learn problem solving skills.
Cognitive

Cognitive/Affective

Cognitive

Cognitive

Cognitive

Affective

Affective

Cognitive

Cognitive

Cognitive/Affective

Affective

Cognitive/Affective

Cognitive

Cognitive

Cognitive

Affective

Cognitive

Cognitive/Affective

Affective

Cognitive

Cognitive

Cognitive

Cognitive

Cognitive/Affective

Affective

Cognitive

Affective

Cognitive
3,2

3,4

3,4

3,0

3,2

2,9

3,2

$3,4 \quad 3,2$

$3,0 \quad 4,0$

$2,8 \quad 4,3$

$2,8 \quad 4,0$

$2,4 \quad 2,1$

$3,7 \quad 3,7$

$3,8 \quad 4,3$

$2,8 \quad 2,6$

$2,7 \quad 2,6$

$2,7 \quad 2,6$

$3,2 \quad 3,2$

$4,8 \quad 4,1$

$3,6 \quad 3,4$

$3,1 \quad 3,6$

$2,8 \quad 2,9$

$3,2 \quad 4,4$

$3,2 \quad 3,1$

$3,2 \quad 3,0$

$3,6 \quad 3,5$

$4,1 \quad 3,6$

$1,9 \quad 3,0$

$4,0 \quad 4,0$

$3,0 \quad 3,1$

$3,4 \quad 3,3$

As it is seen in Table 4 there are 16 items related to cognitive domain that refer to students' cognitive (thinking) process in the laboratory. 11 of them are positively worded and 5 of them are negatively worded. Negatively worded items are recoded in order that students' high score contributed to meaningful learning. The results of the study showed that pre-service teachers increased their scores in 3 items in cognitive domain namely "to make decisions about what data to collect", "to consider if my data makes sense", and "to interpret my data beyond only doing calculations" with the average increase in the mean score from post-test to pre-test as 1.3, 1.2, 1.2 respectively. It is remarkable that all these three item are related to collecting and analyzing data. In the second and third steps of ADI (see Table 1), students decide which method to collect data and interpret data to develop an argument. Walker, Sampson and Zimmerman (2011) claimed that these steps help students "to learn how to design and carry out informative investigations, analyze data, and learn how to deal with the ambiguities of empirical work" (p. 1049). It is seen that these steps worked well to fulfill their expectations and pre-service teachers find an opportunity to decide what type of data to need and how to collect them to develop an argument to answer research question. This result is parallel with Walker and Sampson (2013)'s study that shows by means of the steps of ADI students can develop the skills such as deciding which data to collect and how to interpret this data needed to engage in scientific inquiry. In the cognitive domain pre-service teachers'scores did not changed in the following three items; "to be confused about how the instruments work", "get stuck but keep trying", "to be confused about what my data mean" and decreased only 0.1 point in the following six items; "to experience moments of insight", "the procedures to be simple to do", "to be confused about the underlying concepts." "to focus on procedures, not concepts", "to make mistakes and try again", "to learn problem solving skills". Since the scores of post-test and 
pre-test are the same or very similar ( 0.1 point decrease) it can be possible to conclude the cognitive expectations measured with these items were almost fulfilled. There are only four items that participants expectations were not fulfilled namely "to learn critical thinking skills", "to think about what the molecules are doing", "to think about science I already know", "to use my observations to understand the behavior of atoms and molecules" with the average decrease in the mean scores as $0.2,0.3,0.2,0.2$ respectively. These decreases were not dramatic and the items generally related to chemistry. As we explained before all the investigations were not related to chemistry and the emphases on the underlying explanations of observed phenomenon with respect to nature of particles might be missing.

Table 4 shows that there are eight items related to affective domain. 5 of them are negatively worded and 3 of them are positively worded. Negatively worded items are recoded again in order that students' high score contributed to meaningful learning. It can be concluded from the results that in affective domain pre-service teachers' experiences were better than their expectation. Pre-service teachers increased their scores in five items in affective domain namely "to worry about finishing on time", "to be excited to do science" , "to be nervous about making mistakes", "to develop confidence in the laboratory", "to feel intimidated" with the average increase in the mean scores as $0.8,1.0,1.5,0.5,0.4$ respectively. Two of the items (to be frustrated and to be confident when using equipment)' scores increased very slightly ( 0.1 point) from pre to post -test. Overview of the results showed that students' confidence in laboratory was grown and their eager about doing laboratory was increased in the ADI instructional model. This is consistent with literature showing that when students attend laboratories where they find opportunity to learn by engaging scientific practices, they develop positive attitudes towards laboratory and they develop confidence in laboratory (Azizoğlu \& Uzuntiryaki 2006; Güneş, Şener, Topal Germi, \& Can 2013; Hofstein 2004). Actually it is known that using chemical materials and using time effectively to complete an experiment are some issues about which students might have anxiety in chemistry laboratory (Eddy, 2000). So ADI model can be thought successful in not increasing students' anxiety levels. There is only one item in affective domain where pre-service teachers' experiences surpassed their expectation on the feelings about using chemicals. This item is "to be nervous when handling chemicals" with the average decrease of 0.7 point. Actually this result corroborates previous research that has consistently shown that students need to be given sufficient time and opportunities for interaction and reflection in chemistry laboratory in order to decrease their anxiety levels (e.g. Gunstone \& Champagne, 1990). This result is not surprising since we have only two experiment about chemistry and it is understood that these are not sufficient to give students enough opportunity to be familiar with chemicals.

Table 4 also indicates that there are 6 items related to cognitive/affective (doing) domain indicating students' practicing in the laboratory. Among them the number of positively worded items is two and the number of negatively worded items is four. Again negatively worded items are recoded in order that students' high score contributed to meaningful learning. In cognitive/affective domain pre-service teachers increased their score only in one item namely "to worry about the quality of my data" with the average increase as 0.5 point. Pre-service teachers "scores did not changed in the following two items; "to feel unsure about the purpose of the procedures" and "to feel disorganized". There are three items that participants expectations were not fulfilled namely "to worry about getting good data", "to be intrigued by the instruments", "to learn science that will be useful in my life" with the average decrease in the mean score as $0.2,0.5$, and 0.2 respectively. Actually it is surprising that preservice teachers worried about getting good data since we gave them opportunity to recollect data when they are not satisfied with their methodology. A possible explanation to this finding might be resulted from the time needed to do extra work to recollect data. Moreover, the result that pre-service teachers' affective expectation about the instruments was not met after ADI instruction is consistent with the literature showing that students have high anxiety about using equipment and chemicals (Kaya \& Cetin, 2012) and they need time and opportunity to interact with them to decrease their anxiety (Bowen, 1999; Högström, Ottander, \& Benckert, 2010).

It is common among three dimension that ADI based laboratory instruction did not help pre-service teachers to engage chemicals more meaningfully. Their expectations about learning how equipment work, handling chemicals safely and being confident in using chemicals did not meet. Unfortunately their expectation about understanding the underlying concepts of observed phenomena in particulate dimension was not met. It is believed that when the number of investigations related to chemistry is increased, students have more opportunity to inquire particulate nature of phenomena. On the other hand it can be said that ADI is very successful in fulfilling pre- 
service teachers expectations related to collecting, analyzing and interpreting data.

\section{Conclusion and Implications}

This study tried to answer whether pre-service teachers' expectations about laboratory can be met by the ADI instructional model. Generally, the ADI instructional model is able to meet pre-service teachers' positive expectations especially in cognitive dimension. Also, it decreased pre-service teachers' negative expectations in cognitive dimension. Moreover in affective domain pre-service teachers' experiences are better than their expectation. We think that these findings support the ADI instructional model gives responsibility and active role to students in designing knowledge through experiences. Overall, the ADI instructional model achieved fulfilling students' expectations that are ideal for all laboratory conditions.

There are several issues that born out from the results of this study and can be investigated in the future. First of all, the effect of instructor in identifying students' expectation/experiences can be investigated. Secondly, it will be useful to determine whether the number and nature of ADI activities effect students' expectation/experiences. Thirdly, it will be interesting to study with high or middle school students. Finally, researchers can make interviews with students' to take in-depth information about their expectation/experiences in order to design more effective science laboratories.

There are certain inevitable limitations of the present study. First of all, the population size is a major limitation of this study. Specifically, the study was conducted with a small population size; therefore, the generalizability of the findings is limited. To generalize the results of the study, it would be better to conduct the study with larger groups. Secondly the duration of the implementation is another limitation of this study. The study lasted for eleven weeks with six ADI activities. Longer studies might give different results. Lastly the results of this study based on only quantitative data that is obtained from students self-filled likert type items. Qualitative data can give extra information about students' expectation/experiences which help to make better sense of the results. 


\title{
Argümantasyon Tabanlı Sorgulayıcı Araştırma Yönteminin Yazmaya Etkisinin Ötesinde: Öğrencilerin Bilişsel ve Duyşsal Beklentilerinin İncelenmesi
}

\begin{abstract}
Giriş
Fen eğitimi alanında yapılan birçok çalışmada öğrencilerin fen okuryazarı olmalarında laboratuvar etkinliklerinin önemi ve kritik rolü ele alınmıştır (Cetin \& Eymur, 2017; Cheung, 2011; Figueiredo, Esteves, Neves, \& Vicente, 2016; Obenland, Kincaid, \& Hutchinson, 2014; Walker, Sampson, Southerland, \& Enderle, 2016). Ayrıca, bu çalışmalardan ortaya çıkan ortak sonuç geleneksel laboratuvar yönteminin sadece fen konularını aktarmak için kullanıldığı ve maalesef öğrencilere bilim ile ilgili uygulamalar yapma fırsatı vermediği yönündedir (Cooper \& Kerns, 2006). Bu yüzden birçok geleneksel laboratuvar sadece öğrencilerin bazı bulgulara ulaşıp bu bulgulardan sonuçlar çıkarması yönünde tasarlanmıştır. Bu "yemek kitabı" tarzında hazırlanmış laboratuvarlar öğrencilere birçok konu hakkında bilgi sunmasına rağmen, aslında öğrenciler için anlamlı bir öğrenme gerçekleşmemektedir (Domin, 1999; Hofstein \& Lunetta, 2004). Bazı fen eğitimi araştırmacıları bu bulguyu dikkate alarak Argümantasyon Tabanlı Bilim Öğrenme (Wallace, Hand, \& Yang, 2005) ve Modelleme Öğretimi (Hestenes, 1992; Wells, Hestenes, \& Swackhamer, 1995) gibi bilginin yapılanmasını ve araştırma-sorgulamayı ön plana alan yeni laboratuvar öğretim modelleri önermişlerdir. Argümantasyon Tabanlı Sorgulayıcı Araştırma (ATSA) yöntemi de bu yeni laboratuvar yöntemlerine benzer olup öğrencilerin bilimsel okur-yazarlı̆̆ını geliştirmede sadece laboratuvarların deneysel özelliklerine (soru sorma, yöntem geliştirme) değil ayrıca bilimsel iddiaların sunumuna da (argümantasyon, yazı yazma) çok fazla önem vermektedir. Bu model öğrencilere araştırmaları tasarlama ve sonuçları değerlendirme gibi bilimsel uygulamalarda aktif rol vererek anlamlı öğrenme firsatı vermektedir.

Novak'ın anlamlı öğrenme teorisine göre, anlamlı öğrenmenin gerçekleşmesi için, öğrencilerin konuyla ilgili ön bilgisinin olması, yeni bilginin öğrencilere anlamlı bir şekilde verilmesi ve öğrenme sürecinde öğrencilerin aktif olarak rol alması gerekir (Bretz, 2001; Novak, 1993, 2010). Öğrenciler yeni bilgi ile var olan bilgi arasında ilişki kurma aşamasında sorumluluk aldığında, deneyimler yoluyla bilgi üretmede aktif rol almaya başlar (Bretz, 2001; Novak, 1993, 2010). Novak, insanların bu deneyimlerini bilişsel (düşünme), duyuşsal (hissetme) ve psikomotor (yapma) olmak üzere ayırmıştır. Bu bilişsel, duyuşsal ve psikomotor deneyimlerin başarılı şekilde bütünleşmesi ise anlamlı öğrenme ile sonuçlanmaktadır (Novak, J.D, 2010). ATSA yönteminin de öğrencilerin anlamlı öğrenmesini desteklediği düşünülerek, onların bilişsel ve duyuşsal beklentilerinin bu yöntem ile karşılanacağı düşünülmektedir.
\end{abstract}

ATSA yöntemi öğrencilerin anlamlı öğrenmesini desteklemek için Sampson ve Walker (2012) tarafından sunulan sekiz birbiri ile ilişkili basamak içermektedir (Çetin, Metin, \& Kaya, 2016) (Tablo 1).

Tablo 1. ATSA'nın basamakları ve amaçları

\begin{tabular}{ll}
\hline \multicolumn{1}{c}{ Basamak } & \multicolumn{1}{c}{ Amaç } \\
\hline $\begin{array}{l}\text { Görevi ve Yönlendirici } \\
\text { Araştırma Sorusunu } \\
\text { Tanımlamak }\end{array}$ & $\begin{array}{l}\text { Öğrencilerin ilgisini çekmek } \\
\text { Öğrencilerin önceki bilgilerini etkinleştirmek }\end{array}$ \\
& \\
$\begin{array}{l}\text { Araştırma Yöntemini } \\
\text { Tasarlamak ve Veri } \\
\text { Toplamak }\end{array}$ & $\begin{array}{l}\text { Öğrencilere araştırma tasarlama ve uygulama firsatı vermek } \\
\text { Ögrencilere ihtiyaç duydukları veri türüne ve nasıl toplayacaklarına }\end{array}$ \\
\end{tabular}


Verileri Analiz Etmek ve Araştırma Sorusuna Geçici Bir Argüman Üretmek

Argümantasyon

Açık ve Yansıtıcı Tartışma

Araştırma Raporu Yazmak

Akran Değerlendirmesi Yapmak

Araştırma Raporlarını Düzenleyerek Tekrar Sunmak
Öğrencilere iddialarını, bu iddiaların kanıtlarını ve kanıtlarının gerekçelerini içeren geçici bir argüman geliştirme firsatı vermek

Öğrencilerin bilgilerini tartışmasını ve paylaşmasını sağlamak Öğrencilere argümanları ile ilgili dönütler alma şansı vermek

Öğrencilerin diğer gruplarda arkadaşları ile paylaşımlarından elde ettikleri bilgi ve tecrübeleri paylaşmalarını sağlamak

Öğrencilerin yazılı tartışmanın nasıl yazıldığını öğrenmesini sağlamak

Öğrencilere iyi bir inceleme raporunun nasıl olması gerektiğini anlama şansı sağlamak

Öğrencilere kendi akranlarından dönüt alma firsatı sağlamak

Öğrencilerin yazdıklarını düzeltmesini ve geliştirmesini sağlamak

Alan yazında ATSA yönteminin Amerika'da lise öğrencilerinin biyoloji ve kolej öğrencilerinin kimya yeterliliklerini artırmasına etkisini inceleyen çalışmalar bulunmaktadır (Strimaitis, Southerland, Enderle, Grooms, \& Sampson, 2017, Walker, Sampson, Grooms, Anderson, \& Zimmerman, 2012). Genellikle, ATSA ile ilgili çalışmalar bu yöntemin yazı yazma üzerindeki etkisi ile ilgilidir (Sampson, \& Walker, 2012, Walker, Sampson, Grooms, Anderson,\& Zimmerman, 2012). Alan yazına göre, ATSA öğretim modelinin öğrencilerin daha iyi yazmasına yardım ettiğine dair şüphe yoktur. Fakat ATSA öğretim yönteminin öğrencilerin bilişsel ve duyuşsal beklentilerini etkisini araştıran herhangi bir çalışma bulunmamaktadır. Bu çalışmanın amacı, öğrencilerin ATSA yöntemine göre tasarlanmış laboratuvar uygulamalarından sonra bilişsel ve duyuşsal beklentilerinin karşılanıp karşılanmadığını incelemektir.

\section{Argümantasyon Tabanlı Sorgulayıcı Araştırmanın Teorik Çerçevesi}

ATSA yöntemi sosyal yapılandırmacı öğrenme teorilerine dayanmaktadır (Driver, Asoko, Leach, Mortimer, \& Scott, 1994; Anderson, 2007; Scott, Asoko, \& Leach, 2007). Bu yaklaşım, bilginin bireyden bireye transfer edilerek değil de, ancak öğrenen tarafından aktif olarak yapılandırıldığı varsayımına dayanmaktadır (Driver, Asoko, Leach, Mortimer, \& Scott, 1994). Bu yapılandırma da bireysel ve sosyal süreçle oluşmaktadır. Sosyal öğrenme süreci insanların birbiri ile destekleyici ve eğitici etkileşimine dayanırken, kişisel süreç ise bilginin ve anlamanın kişisel olarak yapılandırmasını içerir. Bu teorik çerçevenin öğretim modelleri için iki önemli sonucu vardır. Bunlardan biri öğrencilerin deneyimlerinden öğrenmeleri için otantik bilimsel uygulamalara ihtiyaç duyduğudur. Diğeri ise öğrencilerin bilgi ve normları öğrenmesi için bilimsel uygulamaların ayrıca eğitici olması gerektiğidir.

Duschl, Schweingruber ve Shouse argümantasyonu “Amaçları fikir ve kanıt arasındaki ilişkiyi ortaya çıkarmak olan mantıksal söylem” olarak tanımlamaktadır ( Duschl, Schweingruber, \& Shouse, 2007, p.33). Bilimsel argümantasyon iddia, kanıt ve kanıtın gerekçesini içermelidir. Kanıt, toplandıktan sonra iddiayı ispat ve açıklığa kavuşturmak için kullanılan verilerdir. Bu kanıt, 1) zamanla eğilimi, (2) gruplar arasındaki farkı veya (3) bir ilişkiyi açıklamalıdır. Bilimsel bir argümanın kanıtlarının gerekçelendirilmesi ise kanıtların ilişkisine ve geçerliliğine atıfta bulunmaktadır. Teorik altyapısına bağlı olarak, ATSA öğretim modeli öğrencilere aktif olarak daha özgün ve daha eğitsel laboratuvar aktiviteleri yapma firsatı vermek için önerilmiştir. Bize göre, ATSA öğrencilere deneyimler yoluyla bilgi üretmede aktif rol vererek öğrencilerin laboratuvar hakkındaki bilişsel ve duyuşsal beklentilerini karşılayabilecektir. 


\section{Araştırma Sorusu}

Çalışmanın amacı doğrultusunda, bu çalışmanın araştırma sorusu aşağıdaki gibidir:

ATSA öğretim modeline göre tasarlanmış fen laboratuvarı dersindeki bilimsel uygulamalar, fen bilgisi öğretmen adaylarının bilişsel ve duyuşsal beklentilerini karşılayabilir mi?

\section{Yöntem}

Bu çalışmada, öğretmen adaylarının fen laboratuvarındaki bilişsel ve duyuşsal beklentilerinin, deneyimleri tarafından karşılanıp karşılanmadığını belirlemek amacıyla tek gruplu ön-test son-test deseni kullanılmıştır.

\section{Örneklem}

Bu çalışmaya, bir devlet üniversitesinden seçilen 3. sınıf 32 (28 kız, 4 erkek) fen bilgisi öğretmen adayı katılmıştır. Öğrenciler 21 ile 23 yaş aralığındadır. Öğrenciler, 2014/2015 öğretim yılı birinci yarıyılında ATSA modelini bilen ve bu modelin uygulamasında tecrübeli bir öğretim üyesi tarafından verilen Fen Laboratuvarı dersine katılmışlardır. Katılımcılar bu çalışmadan önce Genel Kimya I-II, Genel Biyoloji I-II ve Genel Fizik I-II laboratuvarlarını tamamlamışlardır. Çalışmaya katılan fen bilgisi öğretmen adayları, araştırmacılara yakınlıkları ve erişilebilir olmaları nedeniyle seçilmiştir.

\section{Veri Toplama Aracı}

Bu çalışmada Galloway ve Bretz (2015) tarafından geliştirilen Laboratuvarda Anlamlı Öğrenme Ölçeği (LAÖÖ) kullanılmıştır. Ölçeğin amacı laboratuvar dersinde öğrencilerin öğrenmelerinin bilişsel ve duyuşsal boyutları ile ilgili beklentilerini ve deneyimlerini ölçmektir. Ölçeğin orjinali kimya laboratuvarı için hazırlandığından öğrencilerin fen laboratuvarlarındaki deneyim/beklentilerini anlamak için araştırmacılar gerekli maddeleri fen olarak değiştirmiştir. Ölçek, araştırmacıların tekrar düzenleyerek 5'li likert tipinde hazırladığı 31 (16 bilişsel, 8 duyuşsal, 6 bilişsel/duyuşsal) madde içermektedir. Katılımcılardan her bir maddeye katılma derecelerini göstermeleri istenmiştir. Ölçekte, 14 tane olumsuz madde bulunmakta olup yüksek puanların anlamlı öğrenmeye katkıyı göstermesi için bu maddeler ters kodlanmıştır. Araştırmacılar maddeleri bağımsız olarak Türkçe'ye çevirmişler ve anlaşmazlıkların olması durumunda çözmek için bir araya gelerek ortak bir karara varmışlardır. Maddelerin uygunluğundan emin olmak için anket Türkçe alanında ve fen eğitiminde uzman kişiler tarafından kontrol edilmiş ve ankete son hali verilmiştir.

\section{Uygulama}

Üçüncü sınıf fen bilgisi öğretmen adayları ATSA etkinliklerine 11 hafta boyunca düzenli derslerinin bir parçası olarak katılmıştır. Öğretmen öğrencileri rastgele 4'lü veya 5'li gruplara ayırmıştır. On grup her hafta 4 saatlik bir laboratuvar dersine katılarak altı ATSA etkinliği gerçekleştirmiştir. ATSA etkinlikleri kimya, biyoloji ve fizik ile ilgilidir. Bu aktiviteler, yoğunluk, gazlar, çimlenme, lamba parlaklığı, enzimler gibi kavramları araştırmak için tasarlanmıştır (Tablo 2). Bu etkinlikler araştırmacılar tarafından daha önce fen laboratuvarlarında kullanılmış ve istenilen şekilde çalışıp çalışmadığı denenmiştir (Cetin \& Eymur, 2017; Eymur \& Cetin, 2017; Erenler, 2017).

Tablo 2. Aktivitelerin Tanımı

\begin{tabular}{ll}
\hline Aktivitenin Adı & Yönlendirici Araştırma Sorusu \\
\hline Yoğunluk & Bilinmeyen maddelerin kimliği nedir? \\
Gazlar & Gazların hacim ve sıcaklıkları arasındaki ilişki nedir? \\
Çimlenme & Çimlenmeyi etkileyen faktörler nelerdir? \\
Lamba Parlaklığı & Lamba parlaklığını etkileyen faktörler nelerdir? \\
Enzimler & Enzimlerin çalışmasını etkileyen faktörler nelerdir? \\
Basit Sarkaç & Sarkacın salınım sayısını etkileyen faktörler nelerdir? \\
\hline
\end{tabular}

Her bir ATSA etkinliği, öğretmenin haftanın yönlendirici sorusunu, konuyla ilgili ön bilgileri ve kullanılacak malzemelerin listesini içeren bir metni dağıtması ile başlamıştır. . Her bir araştırma için birinci basamakta verilen araştırma soruları Tablo 2' de sunulmuştur. Öğretmen adayları araştırma sorusunu cevaplamak ve araştırmayı tasarlanmak için gruplar halinde çalışmışlardır. Örneğin yoğunluk aktivitesinde gruplar toz halindeki kimliği bilinmeyen maddenin kütlesini ve hacmini hesaplamaya çalışmışlardır. Bu aşamada her grubun hacim hesaplamak 
için kullandığı yöntem farklı olmuştur (dereceli silindire koyma, suda çözme, sıkıştırma gibi). Veri toplama sürecinden sonra, öğretmen adayları verileri açılayarak ve analiz ederek geçici bir argüman geliştirmişlerdir. "Kimliği bilinmeyen toz madde tuzdur çünkü bu maddenin yoğunluğunu $2.1 \mathrm{~g} / \mathrm{cm}^{3}$ bulduk. Bize verilen yoğunluk değerleri listesinde bulduğumuz değere en yakın olan tuzdu.” argümanı öğrencilerin yoğunluk aktivitesi için oluşturdukları argümana örnek gösterilebilir. Argümantasyon oturumunda büyük kartonlar kullanılarak, öğretmen adayları bu argümanlarını diğer gruplara gösterişlerdir. Argümantasyon oturumunda, öğrenciler hem kendi argümanlarını sunmuşlar hem de diğer arkadaşlarının ortaya koyduğu argümanları eleştirmişlerdir. Argümantasyon oturumundan sonra ise her bir grup deneyimlerini ve düşüncelerini paylaşmak için yansıtıcı bir tartışma yapmıştır. Bu firsattan sonra, her öğrenci yönlendirici araştırma sorusunu cevaplamak için ayrı ayrı araştırma raporu yazarak öğretmene sunmuştur. Bu yazılan bireysel raporlar, bilimsel argüman yazılarının kalitesini artırmak için akranları tarafından çift-körlü düzeltilmiştir. ATSA öğretim modelinin son aşamasında her öğretmen adayı akran dönütlerine göre kendi araştırma raporlarını tekrar düzeltmişlerdir.

\section{Bulgular ve Tartışma}

Bu bölümde araştırma sorusuna ilişkin betimleyici analizler verilmiştir. Ayrıca, araştırma sorusu ve analiz sonuçlarına dayanarak kısa tartışmalar da sunulmaya çalışılmıştır. Tablo 3, LAÖÖ’ nün bilişsel, duyuşsal ve bilişsel / duygusal boyutlarının beklenti (ön test) ve deneyimler için (son test) betimleyici istatistiklerini göstermektedir.

Tablo 3. LAÖÖ'ün ön-test ve son-test için betimleyici analizleri

\begin{tabular}{llllll}
\hline Boyutlar & $\begin{array}{l}\text { Öğrenci } \\
\text { sayısı }\end{array}$ & Min. & Maks. & Ortalama & $\begin{array}{l}\text { Standart } \\
\text { Sapma }\end{array}$ \\
\hline Ön-bilişsel & 32 & 43 & 61 & 52,0 & 6,2 \\
Son-bilişsel & 32 & 42 & 65 & 53,0 & 5,1 \\
Ön- duyuşsal & 32 & 14 & 67 & 24,8 & 7,9 \\
Son-duyuşsal & 32 & 17 & 71 & 29,0 & 8,7 \\
Ön bilisssel/duyuşsal & 32 & 10 & 22 & 21,1 & 3,0 \\
Son bilişsel/duyuşsal & 32 & 12 & 26 & 20,5 & 2,8 \\
\hline
\end{tabular}

Tablo 3'te görüldüğü gibi öğretmen adaylarının bilişsel boyuttaki ön-test ve son-test puanları birbirine çok yakındır ( $\bar{X}=52$ ön-test ve $\bar{X}=53$ son-test). Yine benzer olarak bilişsel/duyuşsal boyuttaki ön-test puanları sontestte çok az değişmiştir ( $\bar{X}=21.1$ ön-test ve $\bar{X}=20.5$ son-test $)$. Öğrencilerin değişmeyen puanları beklentilerinin deneyimleri tarafından gerçekleştĭgi şeklinde yorumlanabilir. Duyuşsal boyut incelendiğinde, ön-test puanlarının son-testte arttı̆̆ı görülmektedir bu da öğrencilerin deneyimlerinin beklentinin üzerine ifade etmektedir ( $\overline{\mathrm{X}}=24.8$ ön-test ve $\bar{X}=29$ son-test). Sonuç olarak her üç boyutta da son-test puanlarında herhangi bir anlamlı düşüş gözlenmediğinden, öğrencilerin beklentilerinin deneyimlerini çok da aşmadığı sonucuna varılabilir.

Genel olarak beklentilerin karşıllandığı sonucu göz önünde bulundurularak, maddelerin ayrıntılı analizi yapılmıştır. Tablo 4, her bir maddenin ön-test ve son-test puanlarını göstermektedir. Katılımcıların son-testte önteste göre çok yüksek puan aldıkları (deneyimlerinin beklentilerinin üzerine çıktığı) maddeler koyu renkle gösterilmiş̧tir. 
Tablo 4. Maddelerin ön-test ve son-test puanları (Maddeler ön-test için hazırlanan formdan alınmıștır)

\begin{tabular}{|c|c|c|c|}
\hline Maddeler & Boyutlar & $\begin{array}{c}\text { Ön-test } \\
\text { ortalama } \\
\text { puanı }\end{array}$ & $\begin{array}{c}\text { Son-test } \\
\text { ortalama } \\
\text { puanı }\end{array}$ \\
\hline \multicolumn{4}{|l|}{$\begin{array}{l}\text { Bu dönem fen laboratuvarında deney } \\
\text { yaparken..........beklerim (ön-test) }\end{array}$} \\
\hline \multicolumn{3}{|l|}{$\begin{array}{l}\text { ifadeler içinde bulunan fiillerin geçmiş } \\
\text { zaman hali kullanılmıștır)(son-test) }\end{array}$} & \\
\hline $\begin{array}{l}\text { hayatımda yararlı olacak fen konularını } \\
\text { öğrenmeyi }\end{array}$ & Bilişsel/Duyuşsal & 3,9 & 3,7 \\
\hline $\begin{array}{l}\text { zamanında bitirme konusunda } \\
\text { endişelenmeyi }\end{array}$ & Duyuşsal & 2,5 & 3,3 \\
\hline $\begin{array}{l}\text { hangi verileri toplanacağım konusunda } \\
\text { kararlar almayı }\end{array}$ & Bilişsel & 3,2 & 4,5 \\
\hline $\begin{array}{l}\text { prosedürün amacı konusunda emin } \\
\text { hissetmemeyi }\end{array}$ & Bilişsel/Duyuşsal & 3,4 & 3,4 \\
\hline $\begin{array}{l}\text { bir şeyin içyüzünü anladığım anlar } \\
\text { yaşamayı }\end{array}$ & Bilişsel & 3,0 & 2,9 \\
\hline $\begin{array}{l}\text { cihazların nasıl çalıştığı konusunda kafamın } \\
\text { karışmasını }\end{array}$ & Bilişsel & 3,2 & 3,2 \\
\hline eleştirel düşünme becerilerini öğrenmeyi & Bilişsel & 3,4 & 3,2 \\
\hline $\begin{array}{l}\text { fen ile ilgili birşeyler yapmak için } \\
\text { heyecan duymayı }\end{array}$ & Duyuşsal & 3,0 & 4,0 \\
\hline hata yapmak konusunda gergin olmayı & Duyuşsal & 2,8 & 4,3 \\
\hline $\begin{array}{l}\text { verilerimin mantıklı olup olmadığını } \\
\text { değerlendirmeyi }\end{array}$ & Bilişsel & 2,8 & 4,0 \\
\hline moleküllerin ne yaptıklarını düşünmeyi & Bilişsel & 2,4 & 2,1 \\
\hline dağınık hissetmeyi & Bilişsel/Duyuşsal & 3,7 & 3,7 \\
\hline laboratuvarda güven geliştirmeyi & Duyuşsal & $\mathbf{3 , 8}$ & 4,3 \\
\hline $\begin{array}{l}\text { iyi veri elde etmek konusunda } \\
\text { endişelenmeyi }\end{array}$ & Bilişsel/Duyuşsal & 2,8 & 2,6 \\
\hline yapılması kolay prosedürlerle uğraşmayı & Bilişsel & 2,7 & 2,6 \\
\hline $\begin{array}{l}\text { altta yatan kavramlar konusunda kafamın } \\
\text { karışmasını }\end{array}$ & Bilişsel & 2,7 & 2,6 \\
\hline çıkmaza girmeyi ama yine de denemeyi & Bilişsel & 3,2 & 3,2 \\
\hline kimyasallarla uğraşırken gergin olmayı & Duyuşsal & 4,8 & 4,1 \\
\hline $\begin{array}{l}\text { zaten bildiğim fen konuları hakkında } \\
\text { düşünmeyi }\end{array}$ & Bilişsel & 3,6 & 3,4 \\
\hline $\begin{array}{l}\text { verilerimin kalitesi konusunda } \\
\text { endişelenmeyi }\end{array}$ & Bilişsel/Duyuşsal & 3,1 & 3,6 \\
\hline hayal kırıklığına uğramış hissetmeyi & Duyuşsal & 2,8 & 2,9 \\
\hline $\begin{array}{l}\text { verilerimi hesaplama yapmak için } \\
\text { kullanmanın ötesinde yorumlamayı }\end{array}$ & Bilişsel & 3,2 & 4,4 \\
\hline $\begin{array}{l}\text { kavramlara odaklanmak yerine prosedüre } \\
\text { odaklanmay1 }\end{array}$ & Bilişsel & 3,2 & 3,1 \\
\hline $\begin{array}{l}\text { atomların ve moleküllerin davranışlarını } \\
\text { anlamak için gözlemlerimi kullanmayı }\end{array}$ & Bilişsel & 3,2 & 3,0 \\
\hline hata yapmayi ve tekrar denemeyi & Bilişsel & 3,6 & 3,5 \\
\hline cihazların ilgimi çekmesini & Bilişsel/Duyuşsal & 4,1 & 3,6 \\
\hline gözü korkmuş hissetmeyi & Duyuşsal & 1,9 & $\mathbf{3 , 0}$ \\
\hline
\end{tabular}


verilerimin ne anlama geldiği konusunda kafamın karışmasını

cihaz kullanırken kendimden emin olmayı

problem çözme becerilerini öğrenmeyi

\section{Bilişsel}

Affective

Bilişsel
4,0

3,0

3,4
4,0

3,1

3,3

Tablo 4’te görüldüğü gibi bilişsel boyuttaki 16 madde öğrencinin laboratuvardaki bilişsel (düşünme) sürecini kastetmektedir. Bu maddelerden 11'i pozitif anlamlı iken 5'i negatif anlamlıdır. Negatif anlamlı maddeler yüksek puanların anlamlı öğrenmeyi göstereceği şekilde yeniden kodlanmıştır. Bu çalışmanın sonuçları öğretmen adaylarının bilişsel boyuttaki 3 maddede puanlarını artırdığını göstermiştir. Bu maddeler ön-testten son-teste ortalama puanların artışının sırasıyla 1.3, 1.2, 1.2 olduğu "hangi verileri toplayacağım konusunda kararlar almayı", "verilerimin mantıklı olup olmadığını değerlendirmeyi" ve "verilerimi hesaplama yapmak için kullanmanın ötesinde yorumlamayı" maddeleridir. Bu sonuçta dikkate değer olan bu üç maddenin de veri toplama ve analiz etme ile ilgili olduğudur. ATSA' nın ikinci ve üçüncü aşamalarında öğrenciler argüman geliştirmek için hangi yöntemi ve verileri kullanacaklarına ve yorumlayacaklarına karar verirler. Walker, Sampson ve Zimmerman (2011), bu adımların öğrencilerin" verileri nasıl analiz edeceklerini, bilgilendirici araştırmaları nasıl tasarlayacaklarını ve uygulayacaklarını, ampirik çalışmalarda belirsizliklerle nasıl başa çıkacaklarını öğrenmelerine" yardımcı olduğunu iddia etmişlerdir (s. 1049). Bu sonuçlara dayanarak bu aşamaların öğretmen adaylarının beklentilerini karşılamak için iyi çalıştığını söylemek mümkündür. Bu sonuç, ATSA yönteminin mekanizmasının öğrencilerin hangi verilerin toplanacağına karar verme ve bu verileri bilimsel bir çalışma için gerekli olacak şekilde yorumlama becerilerini geliştirdiğini gösteren Walker ve Sampson (2013) 'ın çalışması ile paralellik göstermektedir. Ayrıca, öğretmen adaylarının araştırma sorusunu cevaplamak için oluşturacakları argümanda hangi veriye ihtiyaç duyacaklarına ve bunları nasıl toplayacaklarına karar verme firsatı bulduğunu göstermektedir. Bilişsel boyutta öğretmen adaylarının 3 maddede puanları değişmemiştir. Bu maddeler, "cihazların nasıl çalıştığı konusunda kafamın karışmasını", "çıkmaza girmeyi ama yine de denemeyi” ve "verilerimin ne anlama geldiği konusunda kafamın karışmasını” maddeleridir. Ayrıca, "bir şeyin içyüzünü anladığım anlar yaşamayı”, "yapılması kolay prosedürlerle uğraşmayı”, "altta yatan kavramlar konusunda kafamın karışmasını", "kavramlara odaklanmak yerine prosedüre odaklanmayı" "hata yapmayı ve tekrar denemeyi” ve “problem çözme becerilerini öğrenmeyi” gibi 6 maddede sadece 0,1 'lik bir düşüş gözlenmiştir. Ön-test ve son-test puanlarının aynı veya birbirine çok yakın ( 0,1 puanlık düşüş) olduğu göz önüne alınırsa bilişsel beklentilerin neredeyse tamamının gerçekleştiği sonucuna varılabilir.

Bilişsel boyutta sadece dört maddede katılımcıların beklentileri gerçekleşmemiştir. Bu maddelerde 0,2 ve 0,3 puanlık olağanüstü düşüşler göstermeyen "eleştirel düşünme becerilerini öğrenmeyi”, “moleküllerin ne yaptıklarını düşünmeyi”, "zaten bildiğim fen konuları hakkında düşünmeyi” ve "atomların ve moleküllerin davranışlarını anlamak için gözlemlerimi kullanmayı" gibi maddelerdir. Beklentilere kıyasla deneyimlerden elde edilen bu düşük puanlar hem çok ciddi değildir hem de temelde kimya ile ilgili maddelerdedir. Daha önce açıkladığımız gibi, zaten bütün araştırmalar kimya ile ilgili değildir ve yapılan araştırmalarda taneciklerin doğasını açıklayan konular bulunmamaktadır.

Tablo 4, kendine olan güveni arttırma beklentisini gösteren duyuşsal boyutla ilgili sekiz maddeyi göstermektedir. Bunların 5'i pozitif anlamlı 3'ü ise negatif anlamlıdır. Negatif anlamlı maddeler yine yüksek puanların anlamlı öğrenmeyi göstermesi için yeniden kodlanmıştır. Bu bulgulardan da öğretmen adaylarının duyuşsal boyuttaki deneyimlerinin beklentilerinin üzerine çıktığı görülmektedir. Öğretmen adayları "zamanında bitirme konusunda endişelenmeyi", "fen ile ilgili birşeyler yapmak için heyecan duymayı" "hata yapmak konusunda gergin olmayı", "laboratuvarda güven geliştirmeyi” ve "gözü korkmuş hissetmeyi" gibi 5 maddede sırasıyla $0,8,1,0,1,5,0,5,0,4$ puanlık yükseliş göstermiştir. İki maddede ("hayal kırıklığına uğramış hissetmeyi” ve “ cihaz kullanırken kendimden emin olmayı”) ön-testten son-teste puanlar çok az $(0,1)$ bir artış göstermiştir. Bu sonuçlar ATSA öğretim modelinin öğretmen adaylarının laboratuvardaki güveninin yükselmesine ve onların laboratuvarı kullanma istekliliğinin artmasına yardımcı olduğunu göstermektedir. $\mathrm{Bu}$ sonuç, literatürdeki öğrencilerin bilimsel uygulamaları yaparak öğrenme fırsatı buldukları laboratuvarlarda, laboratuvara karşı olumlu tutum geliştirdiklerini ve laboratuvarda kendilerine güven duyduklarını gösteren sonuçlarla tutarlıdır (Azizoğlu \& Uzuntiryaki 2006; Güneş, Şener, Topal Germi, \& Can 2013; Hofstein 2004). Aslında, kimyasal maddelerin kullanılmasının ve deneyi tamamlamak için zamanı etkili bir şekilde kullanmasının öğrencilerin laboratuvarda endişe edebileceği bazı konular arasında olduğu bilinmektedir (Eddy, 2000). Bu yüzden ATSA yöntemi, 
öğrencilerin kaygı düzeylerini arttırmaması açısından başarılı sayılabilir. Duyuşsal boyutta, öğretmen adaylarının, kimyasal kullanımı ile ilgili deneyimlerinin beklentilerini aştığı tek bir madde vardır. Bu madde 0,7 puanlık düşüş ile "kimyasallarla uğraşırken gergin olma" maddesidir. Aslında bu sonuç, öğrencilerin kimya laboratuvarında karşılıklı etkileşim ve düşünme için yeterli zamana ve fırsata sahip olduklarında kaygı düzeylerinin azaldığını gösteren çalışmaları desteklemektedir (ör. Gunstone \& Champagne, 1990). Bu sonuç, uygulama boyunca sadece iki kimya deneyi yapıldığı düşünüldüğünde sürpriz değildir. Yapılan iki kimya deneyinin öğretmen adaylarına kimyasal maddelere aşina olma firsatı vermesi için yeterli olmadığı anlaşılmaktadır. Ayrıca, Tablo 4, altı maddenin bilişsel/duyuşsal boyutta olduğunu ve öğrencilerin laboratuvardaki uygulamalarını göstermektedir. Bunların ikisi pozitif anlamlı iken dördü negatif anlamlıdır. Yine negatif anlamlı maddeler yeniden kodlanarak yüksek puanların anlamlı öğrenmeye katkı sağlayacak şekilde olması amaçlanmıştır. Bilişsel/duyuşsal boyutta öğretmen adayları sadece ortalama 0,5 puanlık artışla "verilerimin kalitesi konusunda endişelenmeyi” maddesinde artış göstermiştir. "Prosedürün amacı konusunda emin olmamayı" ve "dağınık hissetmeyi” maddelerinde öğretmen adaylarının puanları değişmemiştir. Ayrıca, 3 maddede katılımcıların beklentileri karşılanmamıştır. Bu maddeler de sırasıyla ortalama $0,2,0,5$ ve 0,2 puanlık azalmanın olduğu "iyi veri elde etmek konusunda endişelenmeyi”, "cihazların ilgimi çekmesini”" ve "hayatımda yararlı olacak fen konularını öğrenmeyi” maddeleridir. Aslında, öğretmen adaylarının iyi veri etmek için endişe duymaları şaşırtıcıdır, çünkü bu çalışmada yöntemden memnun olmadıklarında onlara tekrar veri toplama şansı verilmiştir. Bu bulguya yol açan sebep yeniden veri toplamak için ekstra zamana ihtiyaç duyulması olabilir. Bunun yanında, ATSA yönteminin öğretmen adaylarının cihazlarla ilgili duyuşsal beklentilerini karşılamadığı sonucu, literatürde öğrencilerin kimyasal ve cihaz kullanımı konusunda kaygılı olduklarını gösteren (Kaya \& Cetin, 2012) ve bu kaygıyı azaltmak için daha fazla zamana ve iletişime ihtiyaç duyduklarını gösteren çalışmalarla (Bowen, 1999; Högström, Ottander, \& Benckert, 2010) uyumluluk göstermektedir.

ATSA tabanlı laboratuvar öğretiminin, öğretmen adaylarının kimyasal maddeleri daha anlamlı bir şekilde kullanmasına yardımcı olmadığı üç boyutta yaygındır. Cihazların nasıl çalıştığını öğrenmek, güvenli şekilde kimyasalları kullanmak ve kimyasalları kullanmada kendine güvenmek konusundaki beklentileri karşılanmamıştır. Maalesef, araştırılan konularda taneciklerin doğası hakkındaki temel kavramları anlama hakkındaki beklentileri karşılanmamıştır. Kimya ile ilgili araştırmaların sayısı arttıkça, öğrencilerin olayların taneciklerin doğasını da sorgulama fırsatını daha çok bulacağı düşünülmektedir. Öte yandan, ATSA'nın öğretmen adaylarının verilerin toplanması, analiz edilmesi ve yorumlanması ile beklentilerini karşılamakta çok başarılı olduğu söylenebilir.

\section{Sonuç ve Öneriler}

Bu çalışma, ATSA öğretim modelinin öğretmen adaylarının laboratuvar konusundaki beklentilerinin karşılanıp karşılanmadığını cevaplamaya çalışmıştır. Genel olarak, ATSA öğretim modeli, özellikle öğretmen adaylarının bilişsel boyuttaki pozitif beklentilerini karşılamıştır. Ayrıca öğretmen adaylarının duyuşsal boyuttaki deneyimleri beklentilerinin üzerine çıkmıştır. Bu bulgular, ATSA öğretim yönteminin öğrencilere deneyimler yoluyla bilgi tasarlarken sorumluluk ve aktif rol verdiğini destekler niteliktedir. Genel olarak, ATSA öğretim yöntemi, öğretmen adaylarının tüm laboratuvar koşulları için ideal olan beklentilerini karşılamayı başarmıştır.

$\mathrm{Bu}$ çalışmanın sonuçlarından doğan ve gelecekte araştırılabilecek birçok konu bulunmaktadır. Her şeyden önce, öğretmenin öğrencilerin beklentilerini/deneyimlerini belirlemedeki etkisi araştırılabilir. İkincisi, ATSA etkinliklerinin sayısının ve niteliğinin öğrencilerin beklentilerini/deneyimlerini etkileyip etkilemediğini belirlemek yararlı olacaktır. Üçüncüsü, ortaokul ve lise öğrencileri ile çalışmak ilginç olacaktır. Son olarak, araştırmacılar, daha etkin fen laboratuvarları tasarlamak için öğrencilerin beklenti/deneyimleriyle ilgili derinlemesine bilgi edinmek için görüşmeler yapabilirler.

Bu çalışmada da kaçınılmaz olan belirli sınırlılıklar vardır. Öncelikle, bu çalışmanın ana sınırlılığı örneklem büyüklügüdür. Özellikle, çalışma küçük bir örneklem ile gerçekleştirildiğinden, bulguların genelleştirilmesi sınırlıdır. Bulguları genelleyebilmek için, çalışmanın daha büyük bir örneklem ile yapılması daha iyi olur. İkinci olarak, çalışmanın süresi diğer bir sınırlılığıdır. Çalışma, altı ATSA etkinliği ile 11 hafta sürmüştür. Belki daha uzun süreli çalışmalar daha farklı sonuçlar verebilir. Son olarak, bu çalışmanın sonuçları sadece öğrencilerin 
doldurduğu likert tarzı nicel verilere dayanmaktadır. Öğrencilerin beklentileri/deneyimleriyle ilgili nitel veriler daha fazla bilgi vererek sonuçları daha anlamlı kılabilir.

\section{References}

Anderson, C. (2007). Perspectives on science learning. In S. K. Abell \& N. Lederman (Eds.), Handbook of research in science education (pp. 3 - 30). Mahwah, NJ: Erlbaum.

Azizoğlu, N. ve Uzuntiryaki, E. (2006). Kimya laboratuvarı endişe ölçeği [Chemistry laboratory anxiety scala]. Hacettepe University Journal of Education, 30, 55-62.

Bretz, S. L.(2001) Novak's Theory of Education: Human Constructivism and Meaningful Learning. Journal of Chemical Education, 78, 107.

Bowen, C. V. (1999). Development and score validation of a chemistry laboratory anxiety instrument (CLAI) for college chemistry students. Educational Psychological Measurement, 59(1), 171-185

Cooper, M., \& Kerns, T. (2006). Changing the laboratory: Effects of a laboratory course on student attitudes and perceptions. Journal of Chemical Education, 83, 1356-1361

Cetin, P.S., \& Eymur, G. (2017). Developing Students' Scientific Writing and Presentation Skills through Argument Driven Inquiry: An Exploratory Study. Journal of Chemical Education, 94(7), 837- 843.

Cetin, P.S., Metin, D., \& Kaya, E.( 2016). Laboratuvar Uygulamalarında Yeni Bir Yaklaşım: Argüman Temelli Sorgulayıcı Araştırma (ATSA) [A new approach to laboratory instruction: Argument driven inquiry]. Ahi Evran University Journal of KirsehirEducation Faculty, 17(2), 223-242.

Driver, R., Asoko, H., Leach, J., Mortimer, E., \& Scott, P. (1994). Constructing scientific knowledge in the classroom. Educational Researcher, 23(7), 5-12.

Domin, D. (1999). A review of laboratory instruction styles. Journal of Chemical Education, 76(4), 543-547.

Duschl, R., Schweingruber, H., \& Shouse, A. (Eds.). (2007). Taking science to school: Learning and teaching science in grades K-8. Washington, DC: National Academies Press.

Eddy, R. M. (2000). Chemophobia in the college classroom: Extent, sources, and students characteristics. Journal of Chemical Education, 77(4), 514-517

Erenler, S. (2017). Argüman Temelli Sorgulayıcı Araştırma Uygulamarının Fen Bilgisi Öğretmen Adaylarının Üstbilisssel Farkindallk Düzeyine ve Yazma Becerilerine Olan Etkisinin İncelenmesi[The effect of argument driven inquirymethod on pre-service teachers' metacognitive awareness and scientific writing skills], Master Thesis, Abant Izzet Baysal University, Bolu, Turkey.

Eymur, G., \& Cetin, P.S. (2017). Argümantasyon Tabanlı Sorgulayıcı Araştırma Yönteminin Öğretmen Adaylarının Fen Öğretimi Öz Yeterlik İnancına Etkisi, [Effects of Argument-Driven Inquiry on Pre-Service Teachers' SelfEfficacy of Science Teaching]. Erzincan University Journal of Education, 19(3), 36-50.

Figueiredo, M.,Esteves, L., Neves, J., \& Vicente, H.(2016) A data mining approach to study the impact of the methodology followed in chemistry lab classes on the weight attributed by the students to the lab work on learning and motivation. Chemistry Education Research and. Practice, 17, 156-171

Galloway, K. R., \& Bretz, S. L. (2015) Development of an Assessment Toolto Measure Students' Meaningful Learning in the Undergraduate Chemistry Laboratory. Journal of Chemical Education, 92, 1149-1158.

Güneş, M. H., Şener, N., Topal Germi, N. ve Can, N. (2013). Fen ve teknoloji dersinde laboratuvar kullanımına yönelik öğretmen ve öğrenci değerlendirmeleri, [Teacher and Student Assessments Regarding to Use of Science and Technology Laboratory]. DicleUniversity Journal of Ziya Gökalp Education Faculty, 20, 1-11 
Hestenes, D. (1992). Modeling games in the Newtonian world. American Journal of Physics, 60, 440 - 454.

Hofstein, A. (2004). The laboratory in chemistry education; thirty years of experience with developments, implementation and research. Chemistry Education: Research and Practice, 5(3), 247-264.

Hofstein, A., \&Lunetta, V. (2004). The laboratory in science education: Foundations for the twenty-first century. Science Education, 88(1), 28-54.

Högström, P., Ottander, C., \& Benckert, S. (2010). Lab work and learning in secondary school chemistry: the importance of teacher and student interaction. Research in Science Education, 40, 505-523.

Kaya, E. \& Cetin, P. S (2012). Investigation of pre-service chemistry teachers' chemistry laboratory anxiety levels. International Journal on New Trends in Education and Their Implications, 3(3), 90-98.

Obenland, C.A., Kincaid, K.; Hutchinson, J.S. (2013). A General Chemistry Laboratory Course. Designed for Student Discussion. Journal of Chemical Education, 91, 1446-1450.

Novak, J. D. (2010) Learning, Creating, and Using Knowledge; Taylor \& Francis Group: New York, NY

Novak, J. D. (1993) Human Constructivism: A Unification of Psychological and Epistemological Phenomena in Meaning Making. International Journal of Personal Construct Psychology, 6, 167-193.

Sampson, V. and Walker, J. (2012) Argument-Driven Inquiry as a way to help undergraduate students write to learn by learning to write in chemistry. International Journal of Science. Education, 34(10), 1443-1485

Sampson, V., Enderle, P., Grooms, J., \& Witte, S. (2013) Writing to learn and learning to write during the school science laboratory: Helping middle and high school students develop argumentative writing skills as they learn core ideas. Science Education 97(5), 643-670.

Scott, P. H., Asoko, H., \& Leach, J. (2007). Students conceptions and conceptual learning in science. In S. K. Abell \& N. Lederman (Eds.), Handbook of research in science education (pp. 31 - 56). Mahwah, NJ: Erlbaum.

Strimaitis, A. M., Southerland, S. A., Sampson, V. D., Enderle, P. J., \& Grooms, J. (2017). The potential of ambitious instruction for fostering science for all: A comparative case study of biology laboratory instruction at two high schools. School Science and Mathematics, 117 (3- 4), 92 - 103.

Walker, J., Sampson, V., Grooms, J., Anderson, B., \& Zimmerman, C.(2012) Argument-Driven Inquiry in undergraduate chemistry labs: The impact on students' conceptual understanding, argument skills, and attitudes towards science, Journal of College Science Teaching, 41(4), 74-81.

Walker, J., \& Sampson, V. (2013). Learning to argue and arguing to learn in science: Argument-Driven Inquiry as a way to help undergraduate chemistry students learn how to construct arguments and engage in argumentation during a laboratory course. Journal of Research Science Teaching, 50(50), 561-596

Wallace, C., Hand, B., \& Yang, E.-M. (2005). The science writing heuristic: Using writing as a tool for learning in the laboratory. In W. Saul (Ed.), Crossing borders in literacy and science instruction (pp. 375-398). Arlington, VA: NSTAPress

Wells, M., Hestenes, D., \& Swackhamer, G. (1995). A modeling method for high school physics instruction. American Journal of Physics, 63(7), 606 - 619. 